\title{
Manajemen Public Relations Mall @ Alam Sutera Dalam Membangun Reputasi
}

\author{
Esther Seruny, H.H. Daniel Tamburian \\ estherseruny@gmail.com,tamburian@gmail.com
}

Fakultas Ilmu Komunikasi Universitas Tarumanagara

\begin{abstract}
Mall @ Alam Sutera is one of the malls located in the Alam Sutera Tangerang area and officially operates on December 12, 2012 with a modern concept by providing shopping, lifestyle, and entertainment experiences for its visitors. With the condition of the mall that still feels the impact of bomb cases that have happened in the past now, the mall, especially public relations, is trying to rebuild its reputation. The purpose of this study was to find out how the management of public relations of Mall @ Alam Sutera in building its reputation again. This research is a qualitative study using a case study method. The theories used in this study include communication science, public relations, public relations management, public relations strategies, and reputation. Data collection in this study uses interviews with Divison Mall@Alam Sutera public relations and Creative Marketing Communication, observation, literature studies, and also by conducting data searches online. The conclusion of this research is Mall @ Alam Sutera is working to rebuild its reputation by conducting programs that can attract visitors.
\end{abstract}

Keywords: Public Relations, Public Relations Strategy, Public Relations Management, Reputation, Mall @ Alam Sutera

\begin{abstract}
Abstrak
Mall@Alam Sutera merupakan salah satu mal yang berada dikawasan Alam Sutera Tangerang dan resmi beroperasi pada 12 Desember 2012 dengan konsep yang modern dengan memberikan pengalaman belanja, gaya hidup, dan hiburan bagi pengunjungnya. Dengan kondisi mal yang masih merasakan dampak dari kasus bom yang pernah terjadi dimasa lalu saat ini pihak mal khususnya public relations sedang berupaya untuk membangun kembali reputasinya. Tujuan dari penelitian ini adalah untuk mengetahui bagaimana manajemen public relations dari Mall @ Alam Sutera dalam membangun reputasinya kembali. Penelitian ini merupakan penelitian kualitatif dengan menggunakan metode studi kasus. Teori yang digunakan dalam penelitian ini diantaranya ilmu komunikasi, public relations, manajemen public relations, strategi public relations, dan reputasi. Pengumpulan data dalam penelitian ini menggunakan wawancara dengan public relations dan Creative Marketing Communication Divison Mall @ Alam Sutera, observasi, studi pustaka, dan juga dengan melakukan penelusuran data online. Simpulan dari penelitian ini adalah Mall @ Alam Sutera sedang berupaya untuk membangun kembali reputasinya dengan melakukan program-program yang dapat menarik pengunjung.
\end{abstract}

Kata Kunci: Public Relations, Strategi Public Relations, Manajemen Public Relations, Reputasi, Mall @ Alam Sutera 


\section{Pendahuluan}

Di era yang serba modern ini masyarakat semakin mudah dalam memenuhi kebutuhannya baik itu sandang, pangan, papan, maupun kebutuhan hiburan. Dalam Kamus Besar Bahasa Indonesia pusat perbelanjaan memiliki pengertian sebagai tempat terbuka yang memiliki tempat untuk berjalan atau berbelanja. Pada saat sekarang ini masyarakat tidak lagi kesulitan dalam mencari suatu barang karena semakin banyak pusat perbelanjaan yang menyediakan berbagai kebutuhan yang diperlukan oleh masyarakat. Pusat perbelanjaan bukan lagi menjadi tempat baru bagi masyarakat baik di kota maupun desa dapat menemukan pusat-pusat perbelanjaan baik berupa minimarket, swalayan, maupun mal. Dalam Kamus Besar Bahasa Indonesia mal memiliki pengertian gedung atau kelompok gedung yang berisi berbagai macam toko-toko di dalamnya.

Tentu saja tidak semua mal dapat bertahan terutama dengan tingginya persaingan dimana setiap mal tersebut berlomba-lomba untuk dapat memberikan pelayanan dan pengalaman yang berbeda apabila mengunjungi mal tersebut. Hal ini membuat beberapa mal terkesan "mati" karena tingkat pengunjung yang kurang. Untuk itu pihak mal harus terus dapat berinovasi dan memberikan layanan yang terbaik kepada para pengunjungnya agar tercipta reputasi yang baik dimasyarakat mengenai mal tersebut.

Menurut Gaotsi dan Wilson dalam buku Public Relations yang dikutip oleh Gassing dan Suryanto mengatakan bahwa reputasi adalah evaluasi yang didapatkan melalui stakeholder terhadap objek atau organisasi yang didasarkan pengalaman (Gassing dan Suryanto, 2016:160). Sedangkan menurut Kamus Besar Bahasa Indonesia reputasi adalah perbuatan dan sebagainya sebagai sebab mendapat nama baik.

Reputasi merupakan sesuatu yang tidak didapat dalam waktu yang singkat tetapi perlu adanya kerja keras, komitmen, serta visi dan misi yang jelas agar dapat menghasilkan reputasi yang baik dimasyarakat. Tentu saja tidak mudah untuk mempertahankan reputasi yang baik dimasyarakat, terlebih lagi mudahnya pemberitaan mengenai isu - isu yang kurang baik yang dapat dengan mudah menghilangkan reputasi tersebut.

Apabila apa yang telah dijaga tersebut rusak maka berakibat pada rusaknya reputasi tersebut, hal ini dapat sangat berpengaruh pada kelangsungan mal tersebut dalam mempertahankan kepercayaan masyarakat. Meskipun mal tersebut mampu mengembalikan reputasinya kembali namun diperlukan upaya agar tidak menimbulkan isu-isu yang dapat berpengaruh pada reputasi tersebut karena sulit untuk menghilangkan reputasi buruk yang pernah dimiliki di mata masyarakat.

Salah satu mal yang terus berupaya untuk membangun kembali reputasi yang baik adalah Mall @ Alam Sutera yang berada dikawasan Alam Sutera Tangerang. Mal yang resmi beroperasi 12 Desember 2012 ini mengangkat konsep modern dengan menawarkan pengalaman belanja, gaya hidup, dan hiburan bagi pengunjungnya. Mall @ Alam Sutera dikelola dan dioperasikan oleh PT Alam Sutera Realty. Tbk yang merupakan anak perusahan dari grup Argo Manunggal (dikutip dari http://www.mallalamsutera.com).

Mall@Alam Sutera sendiri beralamat di Jl. Jalur Sutera Barat kav. 16 Alam Sutera, Tangerang dibangun dengan konsep green environment yang terlihat dari total luas 7,8 ha dengan hampir sepertiga merupakan area hijau. Mall @ Alam Sutera berupaya untuk membangun reputasi yang baik di masyarakat terutama 
setelah kejadian ledakan bom yang pernah dua kali dialami oleh mal tersebut yang berakibat tingkat pengunjung mal tersebut terus mengalami penurunan. Oleh karena itu diperlukan upaya secara maksimal terutama untuk public relations Mall @ Alam Sutera untuk kembali membangun reputasi serta kepercayaan masyarakat kepada mal ini.

\section{Metode Penelitian}

Penelitian yang dilakukan oleh penulis menggunakan pendekatan kualitatif seperti yang dikemukan oleh Creswell yang dikutip oleh Tamburian menjelaskan bahwa penelitian kualitatif merupakan proses untuk memahami masalah melalui penggambaran holistik atas masalah tersebut yang dibentuk dengan kata-kata, melaporkan dengan terperinci sesuai sudut pandang informan, dan disusun dalam latar ilmiah (Tamburian, 2018:82). Peneliti menggunakan penelitian kualitatif agar dapat meneliti secara mendalam mengenai strategi yang digunakan oleh praktisi public relations Mall @ Alam Sutera dalam membangun reputasi perusahaannya terutama setelah mengalami krisis.

Penelitian ini menggunakan metode penelitian studi kasus dimana peneliti mengangkat mengenai suatu kasus bisa berupa organisasi, kelompok, komunitas, sebuah peristiwa, suatu proses, isu atau kampanye. Metode penelitian studi kasus berusaha untuk menemukan makna atau arti dengan menyelidiki proses dan memperoleh pengertian serta pemahaman mendalam dari seseorang, kelompok, situasi, ataupun kondisi (Emzir, 2012:20).

Subjek penelitian ini adalah humas atau public relations dari Mall @ Alam Sutera dalam melakukan manajemen public relations. Sedangkan objek penelitian ini adalah reputasi Mall @ Alam Sutera sebagai salah satu pusat perbelanjaan yang ada di Tangerang beralamat Jl. Jalur Sutera Barat kav. 16 Alam Sutera, Tangerang 15143. Data diperoleh melalui wawancara dan juga obervasi non-partisipan. Narasumber utama dalam penelitian ini adalah Bapak Farid Dermawan, Ibu Meily Anggraini, dan Ibu Adina Lesmana.

\section{Hasil Temuan dan Diskusi}

Menurut Johanna Fawkes (2001) yang dikutip oleh Suwatno menjelaskan mengenai pengertian Public Relations (Suwatno 2018:3) yaitu hubungan masyarakat atau public relations adalah sebuah fungsi manajemen yang khas yang dapat membantu membangun dan memelihara hubungan mutualistik dari komunikasi, pemahaman, penerimaan, dan kerjasama antar organisasi dan publik yang didalamnya melibatkan manajemen masalah atau isu serta membantu manajemen untuk terus mendapatkan informasi dan responsif terhadap opini publik serta mendefinisikan dan menekankan tanggung jawab manajemen untuk melayani kepentingan umum juga membantu manajemen untuk mengikuti perubahan efektif serta berfungsi sebagai sistem peringatan dini dan memanfaatkan penelitian dan teknik informasi etis sebagai alat utamanya.

Adnanputra (1990) menjelaskan mengenai pengertian strategi yang dikutip oleh Ruslan bahwa, strategi merupakan bagian dari suatu rencana sedangkan rencana adalah produk dari perencanaan yang akhirnya perencanaan adalah salah satu fungsi dari proses manajemen. Sehingga didapati pengertian mengenai strategi public relations merupakan alternatif optimal yang dapat dipilih dan ditempuh sehingga 
mencapai tujuan public relations dalam suatu kerangka yang dibuat oleh public relations (Ruslan, 2012:133-134).

Hubungan antara strategi public relations dengan penelitian penulis adalah menjelaskan bagaimana cara atau strategi yang digunakan oleh public relations Mall @ Alam Sutera dalam melakukan manajemen PR agar dapat memperbaiki kepercayaan dan reputasi dari Mall @ Alam Sutera dimata masyarakat. Serta menjelaskan bagaimana strategi yang dilakukan oleh public relations Mall @ Alam Sutera dalam membuat program-program yang sesuai dengan segmentasi pengunjung mal.

Public relations Mall @ Alam Sutera tidak hanya memikirkan kepentingan serta kenyamanan pengunjung tetapi juga harus dapat memperhatikan aspek - aspek yang menjadi kebutuhan dari pengunjung. Hal ini yang menjadi tolak ukur bagi public relations Mall @ Alam Sutera dalam membuat program agar program tersebut dapat menjawab kebutuhan serta sesuai dengan segmentasi pengunjung yang ada. Sehingga sebelum membuat program public relations Mall @ Alam Sutera melakukan survey mengenai apa yang sedang hangat di masyarakat. Selain itu survey tersebut juga dilakukan setelah program tersebut dijalankan tujuannya adalah untuk mengetahui respon dari pengunjung mal mengenai program tersebut.

Apabila respon yang didapat kurang memuaskan maka hal ini akan menjadi pelajaran dan tolak ukur bagi public relations Mall @ Alam Sutera agar tidak mengulangi kesalahan tersebut.

Menurut Cutlip (2005) yang dikutip oleh Ruslan yang dikaitkan dengan salah satu fungsi public relations dalam manajemen humas dalam menjalankan aktivitasnya memiliki fungsi untuk (Ruslan, 2012:39) :

a. Pencarian fakta atau permasalahan (Fact Finding)

b. Perencanaan (Planning)

c. Komunikasi (Communication)

d. Evaluasi (Evaluating)

Pencarian Fakta (Fact Finding): Langkah pertama yang penting dilakukan oleh seorang public relations adalah mencari fakta atau permasalahan yang sedang terjadi. Hal ini bertujuan agar ia mengetahui secara jelas mengenai hal-hal yang berkaitan dengan fakta tersebut sehingga dapat mengambil keputusan yang sesuai serta dapat menjawab permasalahan yang ada. Dalam hal ini public relations Mall @ Alam Sutera melakukan survey mengenai hal-hal yang sedang hangat di masyarakat kemudian dengan berani melakukan trial error dimana public relations Mall @ Alam Sutera. Hal ini bertujuan untuk mengetahui program apa yang sesuai dengan segmentasi dari Mall @ Alam Sutera sehingga pada program selanjutnya dapat membuat program yang sesuai dengan pengunjung.

Perencanaan (Planning): Dalam membuat program tentu saja diperlukan perencanaan yang matang agar program tersebut mendapatkan hasil yang baik dan sesuai yang diharapkan. Dalam membuat perencanaan program public relations Mall @ Alam Sutera harus mengetahui terlebih dahulu siapa segmentasi dari pengunjung mal. Sama seperti pada saat mencari fakta pada perencanaan juga harus mengetahui siapa target yang ingin dituju. Setelah mengetahui target tersebut maka daalam melakukan promosi public relations Mall @ Alam Sutera dapat mengetahui akan menggunakan media apa yang paling sesuai dengan target tersebut. 
Apabila media yang digunakan telah sesuai maka selanjutnya dalah penempatan media promosi tersebut juga harus sesuai dengan target yang ingin dituju sehingga pada saat melakukan promosi tidak salah sasaran.

Komunikasi (Communication): Apabila program tersebut telah dibuat maka perlu dilakukan pengkomunikasian yang baik agar program tersebut dapat tersampaikan dengan baik pula. Komunikasi yang terjalin antar sesama karyawan juga diperlukan agar semua karyawan mengetahui mengenai program tersebut sehingga apabila pengunjung memerlukan informasi dapat segera diberitahukan.

Selain itu media sosial juga merupakan media komunikasi bagi pihak mal dengan masyarakat sehingga dalam penggunaaan media sosial pihak mal dapat berkomunikasi secara langsung dengan masyarakat terutama apabila terdapat keluhan dapat segera ditangani dan diklarifikasi oleh pihak mal agar tidak menimbulkan dampak yang lebih besar.

Evaluasi (Evaluating): Setelah program tersebut dijalankan maka akan diadakan evaluasi untuk melihat bagaimana respon yang didapatkan dari program atau acara yang dibuat oleh Mall @ Alam Sutera dikalangan masyarkat. Dalam evaluasi ini menjadi pelajaran bagi pihak mal apabila akan membuat program program lainnya. Apabila respon yang didapatkan baik maka itu tidak membuat berpuas diri namun memacu untuk membuat lebih baik lagi kedepannya begitu pun apabila respon yang diperoleh kurang baik maka akan menjadi pelajaran agar apabila membuat program tidak melakukan kesalahan-kesalahan seperti itu lagi.

Menurut Gaotsi dan Wilson (2001) yang dikutip oleh Gassing dan Suryanto dalam buku Public Relations, reputasi adalah hasil evaluasi semua stakeholder terhadap objek atau organisasi yang didasarkan oleh pengalaman. Sedangkan menurut Carfi (2004) yang juga dikutip oleh Gassing dan Suryanto, reputasi dan kepercayaan merupakan segalanya. Alasannya adalah melalui reputasi, kita akan memberikan kepercayaan terhadap suatu produk (Gassing dan Suryanto, 2016:160).

Reputasi merupakan hasil dari opini-opini yang ada dimasyarakat mengenai suatu perusahaan tertentu. Reputasi ini bisa merupakan reputasi yang baik ataupun reputasi yang buruk. Apabila reputasi tersebut merupakan reputasi yang buruk maka diperlukan waktu yang lama untuk memperbaiki reputasi tersebut.

Hubungan antara reputasi dengan penelitian penulis adalah bagaimana public relations dan pihak Mall @ Alam Sutera dalam membangun kembali reputasi dari mal tersebut yang sudah tidak tidak baik dimasyarakat. Tentu saja tidak mudah dalam mengembalikan reputasi yang baik tersebut terlebih lagi setelah kasus bom yang pernah terjadi di Mall @ Alam Sutera yang bukan hanya terjadi sekali namun terjadi sebanyak dua kali. Hal ini sangat berpengaruh pada reputasi mal tersebut sehingga membuat pengunjung semakin berkurang.

Oleh karena itu pihak dari Mall @ Alam Sutera yang salah satunya adalah public relations berupaya membangun kembali reputasi tersebut dengan program program serta acara yang dapat mengembalikan kepercayaan masyarakat terhadap Mall @ Alam Sutera salah satunya dengan bekerjasama dengan aparat pemerintahan dalam program dan acara yang dibuat. Hal ini agar sedikit demi sedikit dapat memperbaiki reputasi mal tersebut dan dapat kembali dipercayai oleh masyarakat sebagai salah tempat untuk menghabiskan waktu bersama. 


\section{Simpulan}

Berdasarkan penelitian yang sudah penulis lakukan penulis menyimpulkan beberapa kesimpulan adalah program yang saat ini sedang fokus dilakukan oleh public relations Mall @ Alam Sutera selain membantu mempublikasikan acara adalah mempersiapkan pembukaan foodcourt baru yang memiliki misi untuk memberikan pengalaman makan yang murah dan nyaman kepada pengunjung mal. Kemudian yang menjadi salah satu wadah atau tempat bagi public relations Mall @ Alam Sutera untuk membangun komunikasi dengan masyarakat adalah dengan menggunakan media sosial. Selain menjadi tempat untuk promosi, media sosial juga dimanfaatkan untuk memberikan informasi-informasi mengenai Mall @ Alam Sutera juga menjawab keluhan dan masukan dari masyarakat mengenai mal. Media sosial memiliki dampak yang paling besar dalam membangun reputasi sehingga media sosial yang paling aktif yang dimiliki oleh Mall @ Alam Sutera saat ini adalah Instagram, Facebook, dan Twitter. Salah satu aspek yang menjadi tolak ukur bagi public relations dalam menjalankan manajemen PR adalah dengan melakukan survey untuk mengetahui hal-hal yang terjadi di masyarakat dan menjadi tolak ukur dalam merencanakan program. Salah satu strategi yang digunakan untuk membangun kembali reputasi Mall @ Alam Sutera yang diterapkan adalah dengan memberikan hal-hal yang benar terjadi di masyarakat. Maksudnya adalah dengan tidak memberikan atau menginformasikan hal - hal yang tidak benar hanya untuk membangun reputasi. Dalam pelaksanaan program atau acara yang dibuat harus sesuai dengan tujuan serta visi dan misi yang dimiliki oleh Mall @ Alam Sutera yaitu untuk memberikan pelayanan yang terbaik kepada seluruh pelanggan.

\section{Ucapan Terima Kasih}

Ucapan terimakasih diberikan kepada Fakultas Ilmu Komunikasi Universitas Tarumangara, pembimbing H.H. Daniel Tamburian, dan juga kepada narasumber yaitu Bapak Farid Dermawan, Ibu Meily Anggraini, dan Ibu Adina Lesmana, dan juga kepada semua pihak yang telah mendukung dan membantu penelitian ini.

\section{Daftar Pustaka}

Emzir. (2012). Metode Penelitian Pendidikan Kuantitatif dan Kualitatif. Bandung: PT RajaGrafindo Persada

Gassing, S, Syarifuddin. (2016). Public Relations. Edisi I. Yogyakarta: C.V ANDI OFFSET

Kamus Besar Bahas Indonesia. KBBI Daring. <https://kbbi.kemdikbud.go.id/entri/Pusat\%perbelanjaan>. diakses pada 26 September 2018

Kamus Besar Bahas Indonesia. KBBI Daring. <https://kbbi.kemdikbud.go.id/entri/Mal>. diakses pada 26 September 2018

Mall@ Alam Sutera. About The Mall. $<$ http://www.mallalamsutera.com/information/8/aboutthemall/en\#.W9Xay2gza00> . diakses pada Minggu, 28 Oktober 2018

Ruslan, Rosady. (2012). Manajemen Public Relations dan Media Komunikasi. Jakarta: PT Raja Grafindo Persada 
Esther Seruny, H.H Daniel Tambrian: Manajemen Public Relations Mall @ Alam Sutera Dalam Membangun Reputasi

Suwatno. (2018). Pengantar Public Relation Kontemporer. Bandung: Remaja Rosdakarya

Tamburian, H. (2018). Komunikasi Lintas Budaya Dayak Dalam Menjaga Kerukunan Hidup Umat Beragama. Jurnal Komunikasi, 10(1), 77-86. 